\title{
SISTEM E - PRESCRIBING DAN BARCODE SYSTEM UNTUK RESEP OBAT DI RUMAH SAKIT
}

\author{
Rina Alfah ${ }^{1)}$, Try Viananda Nova Megariani $^{2)}$, dan Rusdina ${ }^{3)}$ \\ 1,2,3) Fakultas Teknologi Informasi, UNISKA MAB Banjarmasin \\ e-mail: rina.alfah.05@gmail.com ${ }^{1}$, novamegariani@gmail.com ${ }^{2)}, \underline{\text { russidina@gmail.com }}^{3)}$
}

\begin{abstract}
ABSTRAK
Untuk meminimalkan medication error (kesalahan pembacaan resep dan dosis) yang dilakukan oleh apoteker maupun asisten apoteker, maka kami membuat aplikasi online e - prescribing, yaitu dokter entry secara langsung resep yang akan diberikan ke pasien, dan apoteker atau asisten apoteker langsung membaca di layar komputer dan langsung menerapkan resep yang sesuai dengan request dari dokter sehingga tidak terjadi kesalahan dan data menjadi akurat serta waktu yang diperlukan bisa lebih cepat. Dalam penelitian ini, kami juga menerapkan barcode system peresepan yang memudahkan apoteker/ asisten apoteker dalam menyesuaikan keakuratan data stok fisik obat, dengan menambahkan barcode system maka masuk dan keluarnya obat akan terkontrol dan akurat sehingga meminimalisir kesalahan dalam pengentrian data pabrik dengan merek obat yang sama. Penelitian ini diimplementasi kan di Rumah Sakit Pertamina Tanjung, Kalimantan Selatan. Development Tools yang di pergunakan adalah Power BuilderV.12 dengan database Sybase. Dari hasil uji kuesioner yang kami berikan kepada user/pemakai Aplikasi E-Pescribing dan bacode system, didapatkan hasil yang memuaskan yaitu: untuk Performance sebanyak $81.82 \%$, Durability 84,24\%, Confermence to Specipication untuk hak akses apotek sebanyak $93 \%$ sedangkan untuk hak akses poli/dokter yaitu $86,6 \%$, untuk Feature $84,24 \%$, realibity $83,64 \%$, dan estetika 79,4\%.
\end{abstract}

Kata Kunci: E-Prescribing, Medication Error, Power BuilderV.12, Sybase, Sistem Barcode

\begin{abstract}
To minimize medication errors (errors in prescription readings and doses) conducted by pharmacists and pharmacist assistants, then we make an online application for e-prescribing, namely the doctor entry directly prescribed to the patient, and the pharmacist or pharmacist assistant immediately reads on the computer screen and immediately apply the recipe in accordance with the request from the doctor so that there is no error and the data becomes accurate and the time needed can be faster. In this study, we also applied a prescription barcode system that allows pharmacists / pharmacist assistants to adjust the accuracy of the physical stock data of the drug, by adding a barcode system, the entry and exit of the drug will be controlled and accurate so as to minimize errors in factory data entry with the same drug brand. This research was implemented at Pertamina Tanjung Hospital, South Kalimantan. The Development Tools used are Power Builder with the Sybase database
\end{abstract}

Keywords: E-Prescribing, Barcode System, Medication Error, Power BuilderV.12, Sybase

\section{Pendahuluan}

SEBUAH permasalahan yang sangat umum yang sering terjadi di Instalasi Farmasi pada sebuah rumah sakit yaitu sangat rentan dengan adanya human error maupun kesalahan dalam penulisan dan pemberian resep obat serta kurang akuratnya stok resep di apotik, sehingga komunikasi antara dokter dan apoteker/asisten apoteker sering terhambat dan membutuhkan proses yang lama sehingga mengakibatkan adanya banyak antrian pasien dalam meminta resep, selain itu apoteker/asisten apoteker tidak konsentrasi dalam memberikan resep begitu juga kadang kala tulisan dokter yang sangat sulit dibaca yang mengakibatkan apoteker/asisten apoteker membaca sesuai dengan huruf depan dan belakang yang terbaca di resep manual serta dosis yang diberikan terkadang tidak jelas dan tidak terbaca [1].

Medication error merupakan masalah yang sering terjadi pada pasien rawat inap. Secara umum Medication error didefinisikan sebagai peresepan, pemberian dan administrasi obat yang salah, yang menyebabkan konsekuensi tertentu atau tidak [2]. Sebuah studi di Yogyakarta (2010) terhadap sebuah rumah sakit swasta menunjukkan bahwa dari 229 resep, ditemukan 226 resep medication error [3]. Dari 226 medication errors, 99.12\% merupakan kesalahan peresepan, 3.02\% merupakan kesalahan farmasetik dan 3.66\% merupakan kesalahan penyerahan. Kemudian menurut F Rahmawati (2002) Skor tertinggi adalah penulisan nama obat yang tidak jelas (92,8\%). Penulisan resep yang bervariasi kerena menggunakan singkatan yang tidak lazim terjadi pada nama obat, satuan metrik dan aturan pakai. Selain berpotensi menimbulkan medication error juga menyebabkan resep tersebut hanya berlaku lokal tidak bersifat universal, contohnya Klorpromazin disingkat CPZ, Haloperidol disingkat HPD, Dekstrometorfan disingkat DMP dan lain sebagainya. Pada aturan pakai, kalau perlu disingkat K/P atau KP, takaran sendok plastik yang ditulis sebagai $\mathrm{Cp}$ atau takaran sendok original. Sebagian besar kesalahan peresepan merupakan akibat dari resep 
yang tidak lengkap. Dokter melakukan kesalahan terbanyak yakni 99.12\%. kesalahan farmasetik meliputi overdosis atau dosis rendah yang inadekuat. Penyerahan obat meliputi preparasi obat yang tidak tepat dan pemberian informasi yang tidak lengkap. Monitoring keamanan dan efikasi obat secara adekuat dapat mencegah terjadinya efek samping. Di Rumah Sakit, pemberian informasi dan kontrol administrasi obat merupakan tantangan yang berat. Selain itu, pada pasien rawat jalan, kontrol penggunaan obat dan keparahan efek samping juga belum dimonitor dengan baik. Interaksi obat dengan obat, makanan, dan bahan kimia dapat mempengaruhi terapeutik pasien.

Misi apoteker adalah untuk membantu memastikan bahwa pasien mendapatkan penggunaan obat yang terbaik dan rasional. Apoteker harus mempelopori, bekerja sama dan disiplin dalam mencegah, mendeteksi dan mengatasi masalah yang berkaitan dengan obat yang dapat mengakibatkan kerugian pada pasien. Adanya faktor risiko dan riwayat penggunaan obat sebelumnya yang mungkin dapat berinteraksi perlu dipantau untuk meminimalkan risiko. Apoteker harus bekerja sama dengan tenaga kesehatan lain untuk memastikan bahwa obat yang digunakan aman. Hal-hal tersebut dilakukan agar dampak negatif dari medication error seperti pemborosan dari segi ekonomi dan menurunnya mutu pelayanan pengobatan (meningkatnya efek samping dan kegagalan pengobatan) dapat diminimalkan. Dalam sebuah rumah sakit tentu nya harus memiliki sebuah sistem informasi untuk memudahkan manajemen kegiatan dirumah sakit tersebut. Sistem informasi dalam organisasi apa pun memiliki elemen penting [4]. Begitu Juga pada bagian instalasi farmasi, jika peresepan masih dilakukan secara manual, akan menimbulkan resiko ada nya Human error kepada pembacaan resep-resep tulisan tangan dokter oleh apoteker/asisten Apoteker.

Menurut Penelitian sebelumnya yang dilakukan oleh Puspa Setia Pratiwi [1] mereka mengidentifikasi kesalahan dalam mengartikan resep obat yang ditulis tangan oleh dokter, kesalahan dalam penentuan dosis obat, sampai lamanya antrian dalam pemesanan obat. E-Prescribing dapat meningkatkan akses ke pelayanan kesehatan dan meningkatkan kualitas dan efektifitas dari pelayanan yang diberikan. Sistem resep elektronik (e-prescribing) meliputi produk obat-obatan dan jenis penyakit dalam menulis resep elektronik. Sistem ini diimplementasikan menggunakan framework CodeIgniter, sistem database menggunakan Phpmyadmin, dan jaringan menggunakan arsitektur client-server.

Dari latar belakang diatas maka kami melakukan penelitian dengan membuat aplikasi E-Prescribing dengan barcode system tetapi dengan menggunakan Development Tools Power Builder dan sybase sebagai database-nya.

\section{LANDASAN TEORI}

\section{A. E-Prescribing}

Menurut uraian pada Centers for Medicare \& Medicaid Services [5], E-Prescribing itu diprakarsai oleh lima buah lembaga kesehatan di Amerika yang sudah terhubungkan melalui Electronic Health (E-Health): The American Medical Association, The American Academy of Family Physicians, The American College of Physicians, The Medical GroupManagement Association, dan The Centre for Improving Medication Management. Pengertian eprescribing adalah resep yang telah ditransmisikan dengan mempergunakan media elektronik yang bisa menghubungkan beberapa atau berbagai informasi di antara dokter, alat pembuat untuk resep elektronik, apotek, serta bagian keuangan, dalam rencana kesehatan baik secara langsung ataupun pula tidak langsung. E-prescribing seperti ini tidak hanya mentransmisikan berbagai informasi secara dua arah saja antara dokter dengan alat pembuat untuk resep elektronik tetapi juga bisa menggabungkan system untuk catatan elektronik kesehatan sperti yang biasa dikenal dengan HER (Electronic Health Record) System. Sistem pencatatan kesehatan elektronik ini adalah bertujuan untuk membantu para pasien dalam merencanakan pengobatan yang lebih lanjut, serta informasi tentang riwayat pengobatan yang sebelumnya, dosis obat-obat yang digunakan, beberapa alergi, dan juga efek dari obatobat yang dikonsumsi. Di dalam sistem e-prescribing ada terdapat dua pilihan sistem yang bisa digunakan yaitu sistem Stand-alone dan juga Sistem HER yaitu dengan modul e-prescribing yang sudah terintegrasi [6].

\section{B. Medication Error}

KepMenKes No 1027 Medical error adalah kejadian yang sudah merugikan pasien akibat kesalahan pemakaian obat, selama dalam masa penanganan oleh tenaga kesehatan yang sebetulnya dapat kita cegah. Medication error merupakan sebuah masalah yang sudah sering terjadi pada pasien rawat inap [2] Namun Secara umum, Medication error didefinisikan sebagai peresepan dan pemberian serta administrasi obat yang salah yang bisa menyebabkan konsekuensi tertentu atau tidak. Keselamatan pasien merupakan suatu disiplin baru dalam pelayanan kesehatan yang mengutamakan pelaporan, analisis, dan pencegahan medical error yang sering menimbulkan Kejadian Tak Diharapkan (KTD) dalam hal pelayanan kesehatan. Dan menurut Depkes RI, Kegiatan skrining resep yang dilakukan oleh tenaga kefarmasian untuk mencegah terjadinya keselahan pengobatan (Medication error) (2008).

\section{Barcode System}

Menurut Jerry Zeyu Gao dan kawan-kawan, barcode (sandi batang) adalah suatu representasi dari informasi yang bisa dibaca mesin (biasanya berupa garis tebal di atas latar belakang putih untuk membuat tinggi dan rendah 
suatu pemantulan yang dikonversi menjadi angka 1 dan 0 [7]. Barcode adalah sebuah kode batang dengan garis hitam hitam diatas background putih. Kode barcode biasanya digunakan pada produk atau barang yang berguna untuk mengkodei suatu kode barang tersebut, dan jika digunakan maka sistem ini akan bekerja dengan koneksi laser barcode serta sebuah software program pembukuan.

\section{Metode PEnELITIAN}

Penelitian ini adalah penelitian eksperimen dan penerapan. Penelitian ini bertujuan untuk membuat suatu sistem yang terintegrasi antara dokter dan asisten apoteker / apoteker, serta membuat sistem yang tepat dalam memberikan info stok obat serta indikasi dan guna obat, serta membuat sistem yang akan memotong stok dengan barcode yaitu dengan menggunakan Power Builder v12.6 dan database Sybase. Untuk Pengumpulan data-data premier seperti data Obat dan pasien Rumah sakit sangatlah penting untuk Penelitian ini. Ketersediaan data base menentukan dalam proses pengolahan sistem Aplikasi E-prescribing. Karenanya, dalam pengumpulan data harus dilakukan teknik yang menjamin bahwa data diperoleh itu benar yaitu data yang diberikan dari pihak rumah sakit sebelum diolah menjadi database yang akurat dan bisa dipertanggungjawabkan. Penelitian kami sudah melaksanakan beberapa proses yaitu:

\section{1) Observasi.}

Kami melakukan Observasi untuk menentukan kebutuhan apa saja yang diperlukan pada objek penelitian yaitu RS Pertamina Tanjung. Kami berangkat ke lokasi untuk Observasi pada tanggal 11 februari 2018 selama tiga hari yaitu sampai tanggal 13 Februari 2018.

\section{2) Interview}

Kami Melakukan Interview kepada pihak-pihak yang terlibat secara langsung dan berkaitan dengan objek penelitian yaitu beberapa dokter, apoteker dan asisten apoteker serta pihak terkait lainnya yang berhubungan dengan penelitian ini

Pengumpulan data dilakukan dengan cara wawancara secara langsung yaitu Instalasi farmasi yang ada dirumah sakit untuk data stok obat dan ke poli pendaftaran pasien untuk data pasien rumah sakit Pertamina Tanjung.

\section{3) Studi Pustaka}

Membaca literatur-literatur baik buku ataupun sumber studi pustaka lainnya yang bisa menjadi sumber informasi yang berguna untuk pengumpulan data dan penelitian ini. Referansi buku sudah kami sertakan pada Daftar Pustaka. Adapun beberapa Perangkat yang diperlukan dalam perencanaan dan pembuatan sistem e - prescribing dan peresepan barcode yaitu:

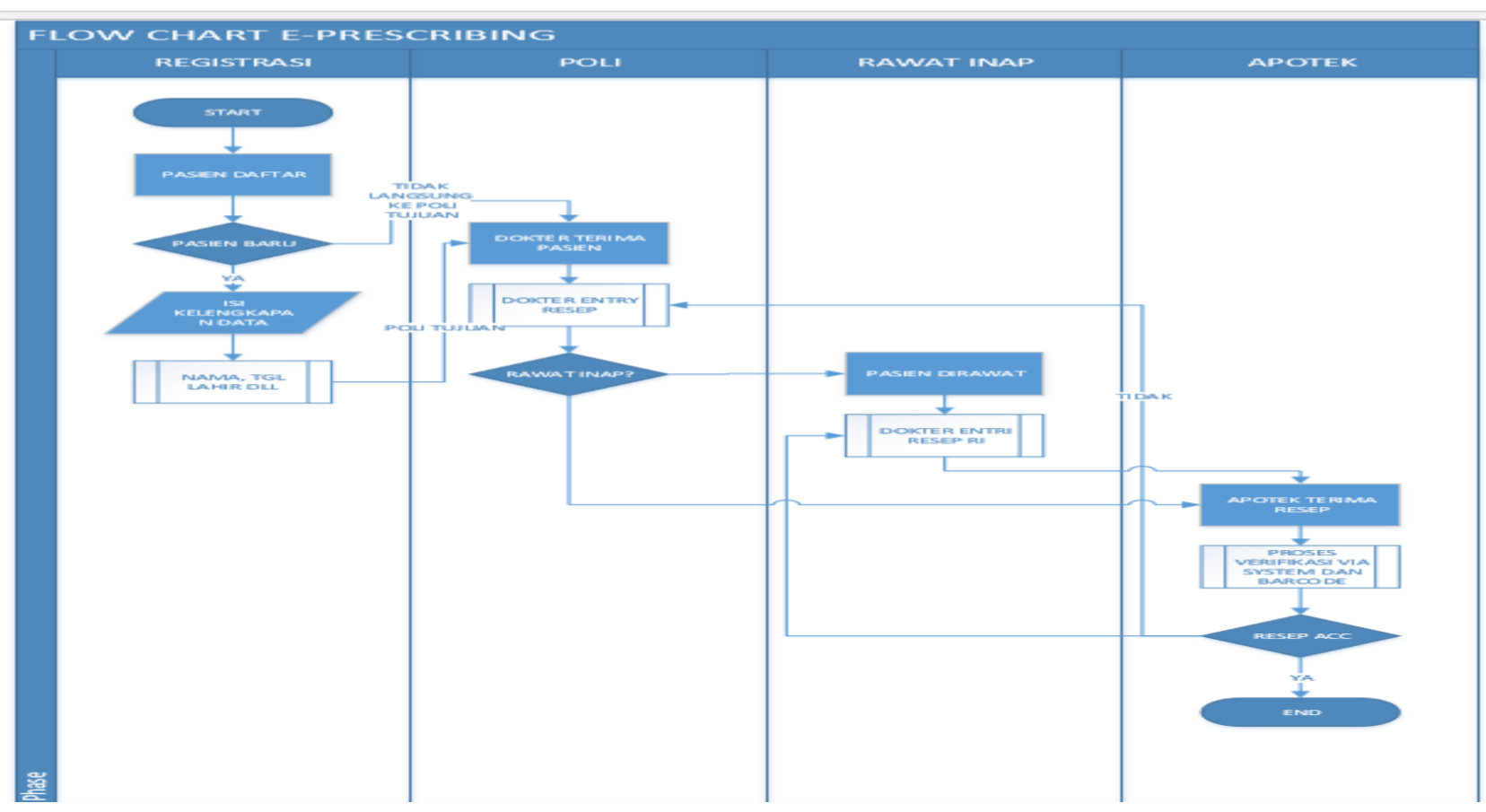

Gambar. 1.Gambaran/ Flowchart Sistem E-Prescribing Rumah Sakit yang dibuat

a. Perangkat Keras

1. Barcode Otomatis

2. $\quad$ PC Desktop / Laptop 


\section{Printer}

b. Software yang digunakan untuk pembuatan sistem:

1. Windows 10 Pro

2. $\quad$ Power Builder (PB) 12.6

3. Microsoft Office 2016 Profesional Plus

4. Sybase

c. Rancangan penelitian

Rancangan FlowChart Aplikasi E-Prescribing yang sudah dibuat dapat dilihat pada Gambar 1.

\section{IMPLEMENTASI SISTEM}

Tampilan antar muka aplikasi yang sudah dibuat ditunjukkan oleh Gambar 2 - Gambar 14.

1) Proses registrasi pasien

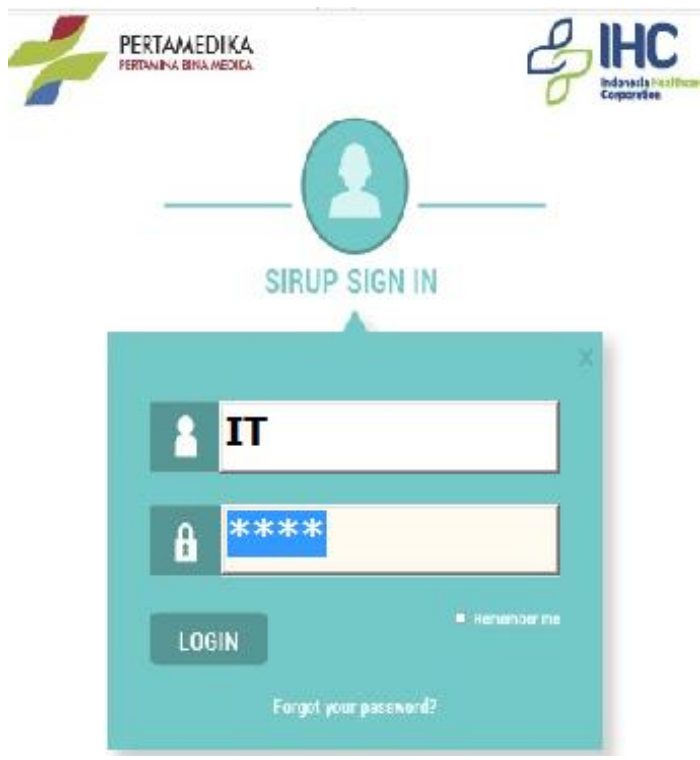

Gambar. 2. UI Form Log in Aplikasi E-Prescribing

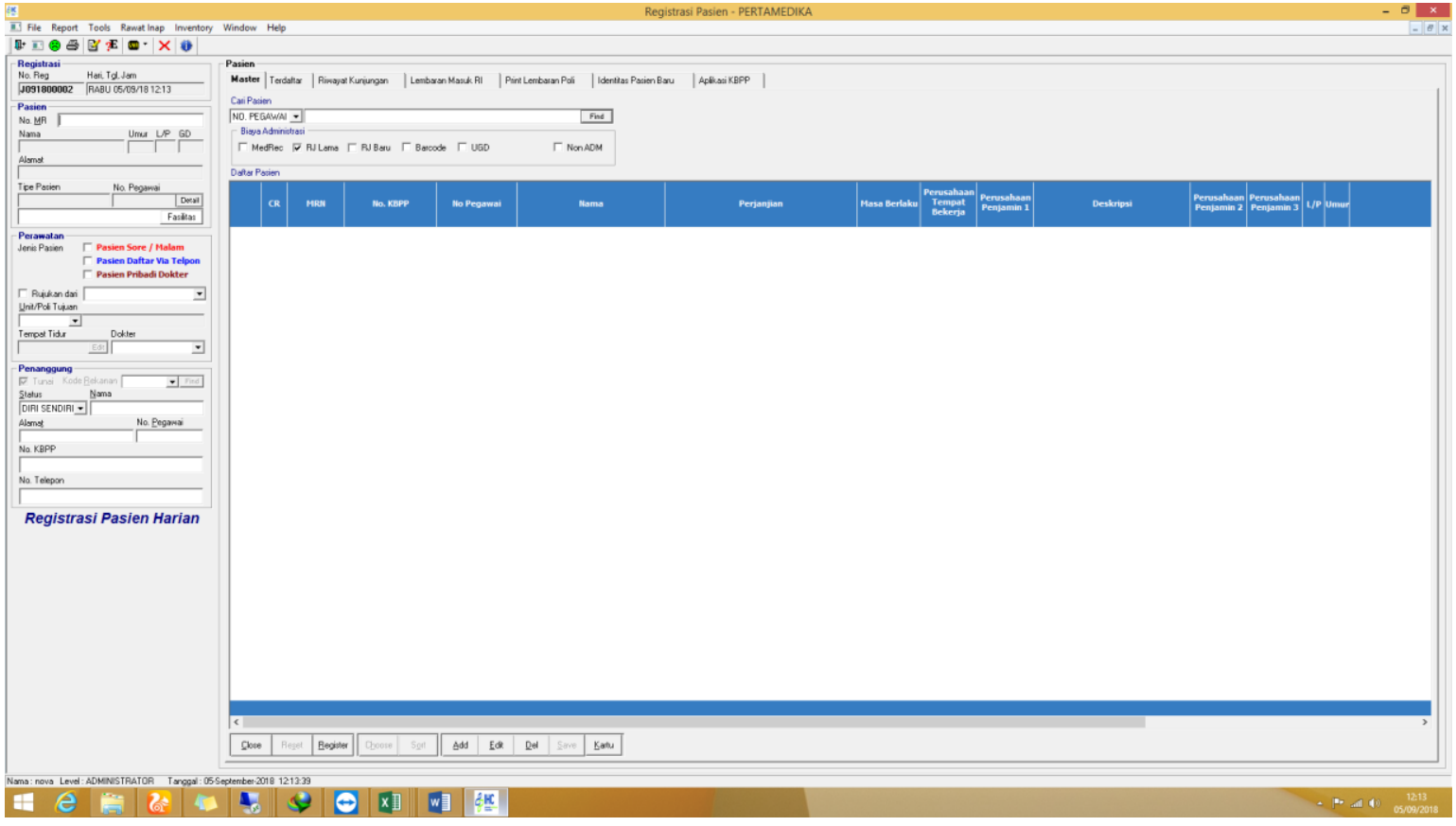

Gambar. 3. Form Registrasi Pasien Rumah Sakit 


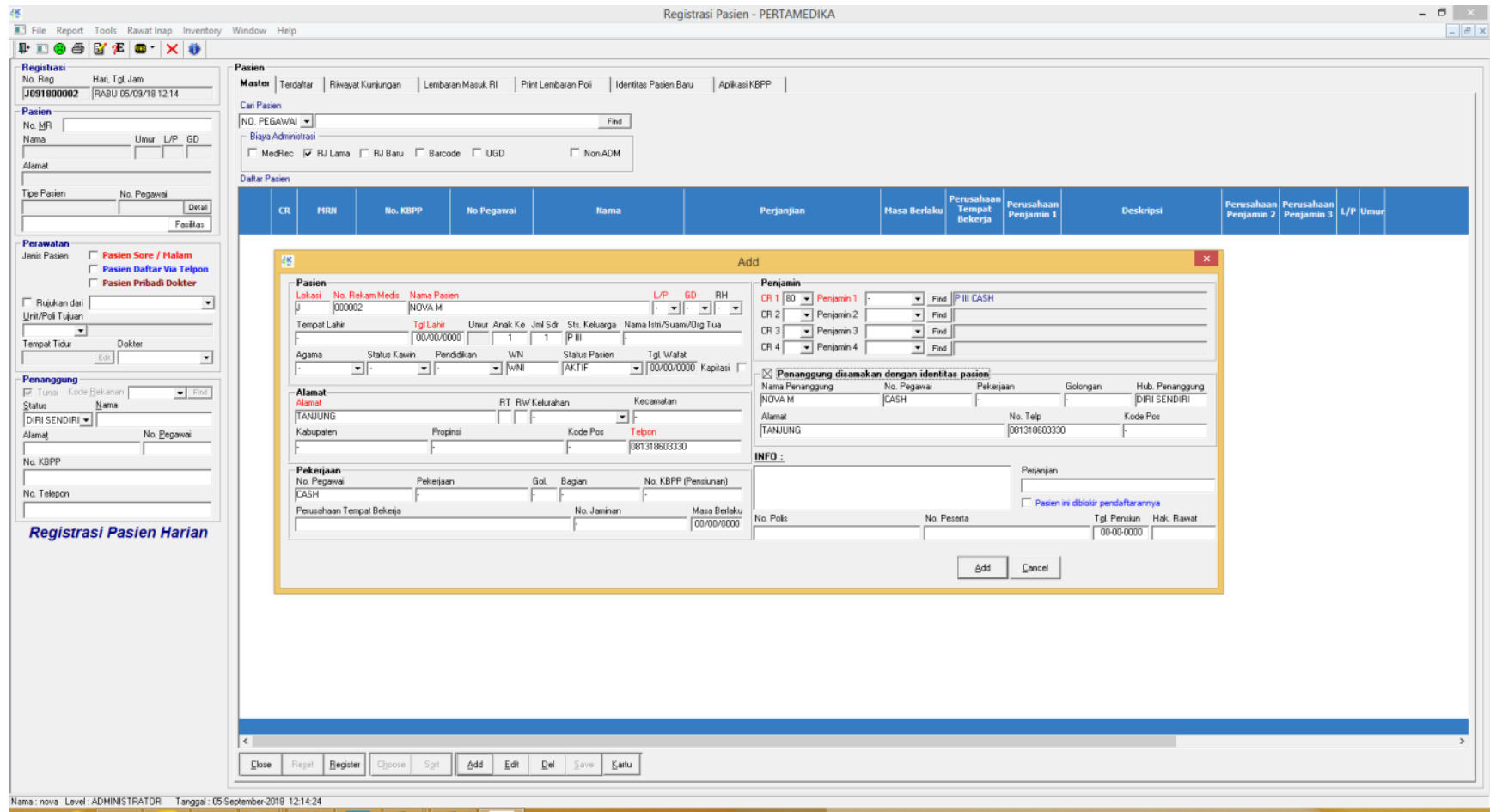

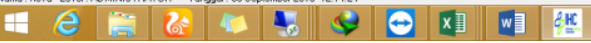

Gambar. 4. Insert Data Pasien Pada Form Registrasi

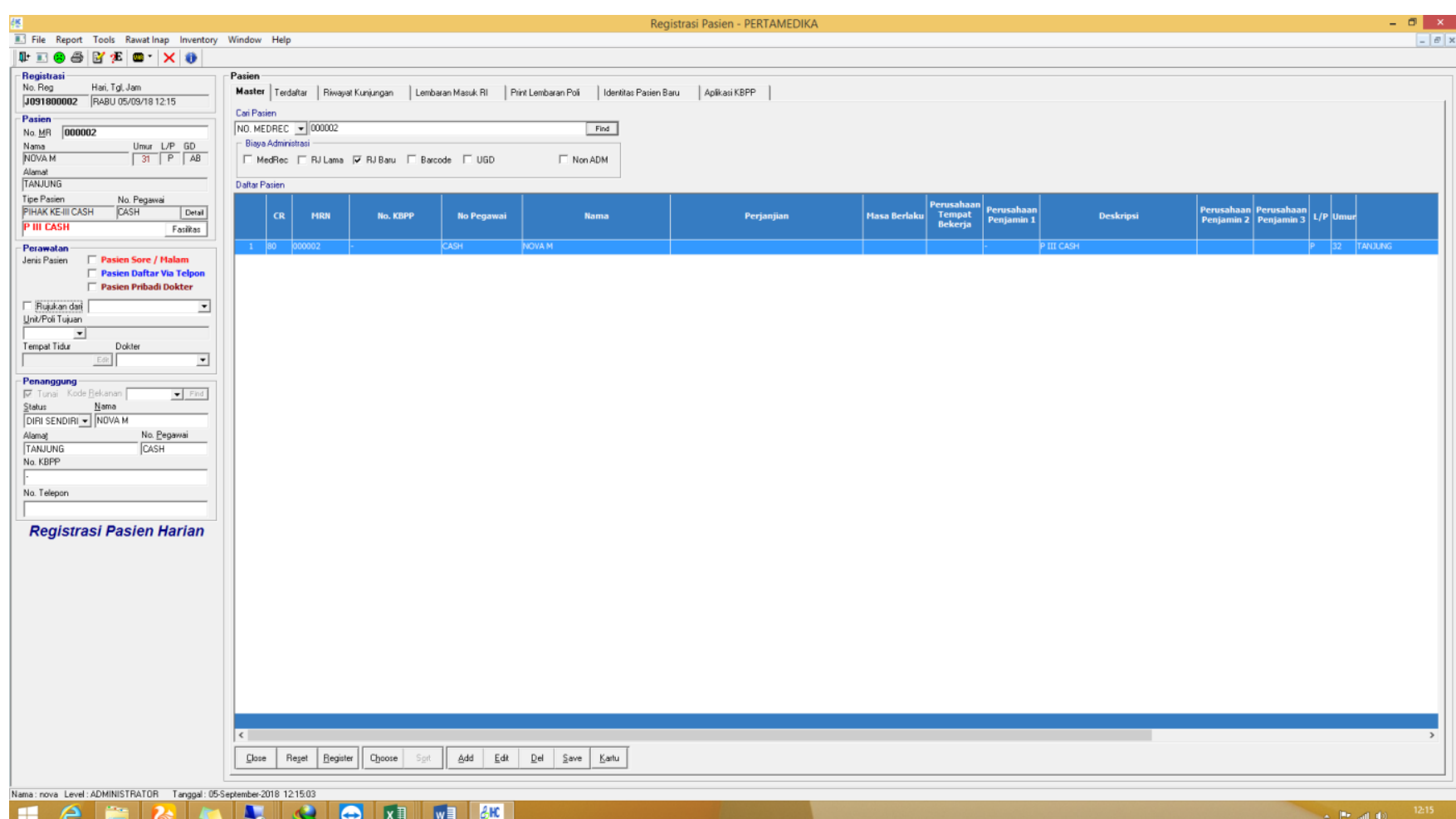

Gambar. 5. Master Data Pasien Pada Form Registrasi Pasien 
JTIULM - Volume 03, Nomor 2, Oktober 2018: 59 - 70

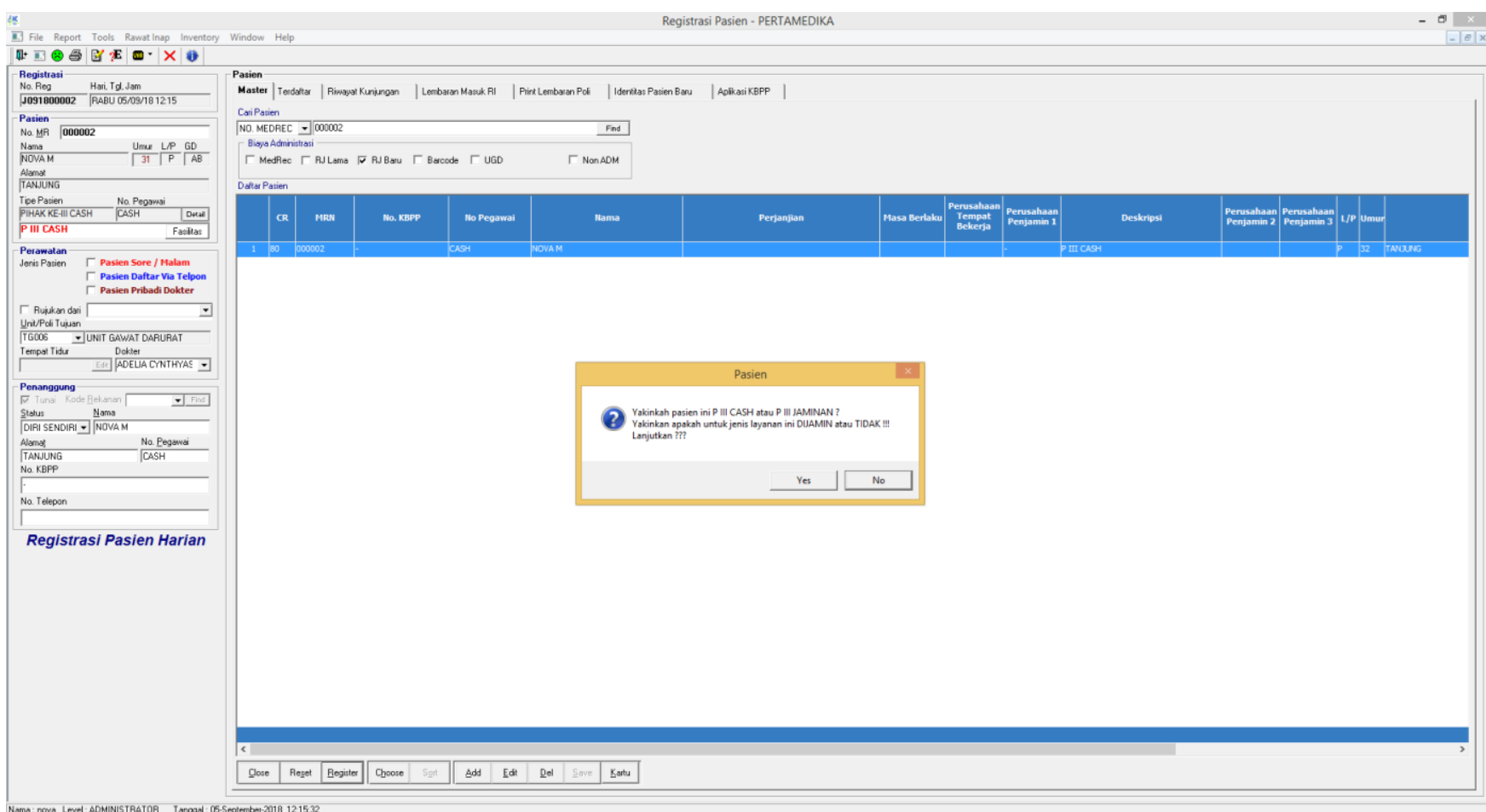

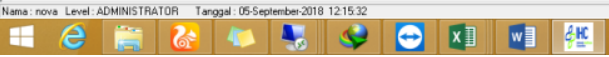

Gambar. 6. Pilihan Jaminan Pembayaran Pasien Pada Form Registrasi Pasien

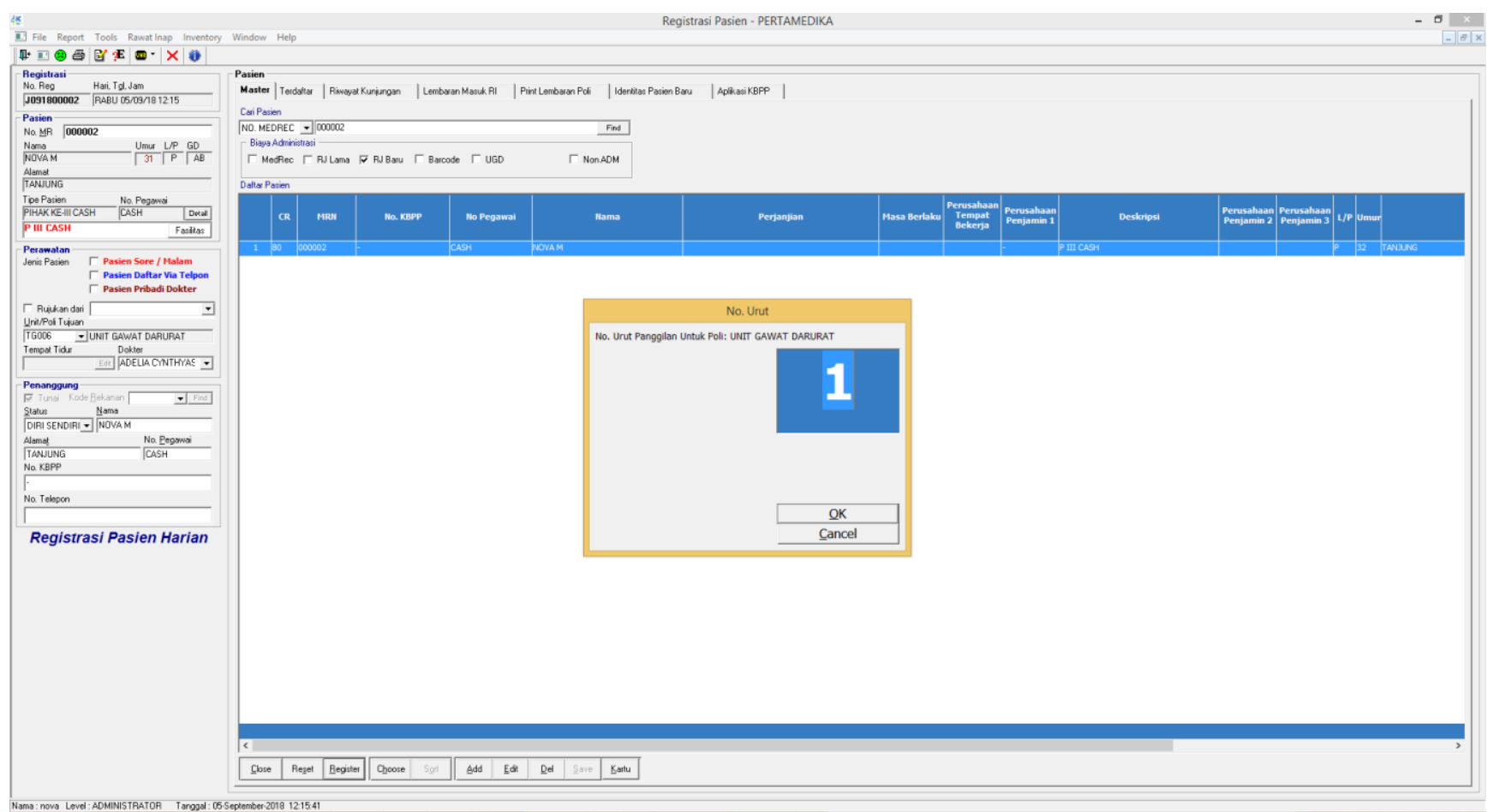

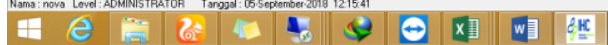

Gambar. 7. Nomer Antrian Pasien 
Alfah, Megariani, dan Rusdina — Sistem E - Prescribing Dan Barcode System Untuk Resep Obat Di Rumah Sakit

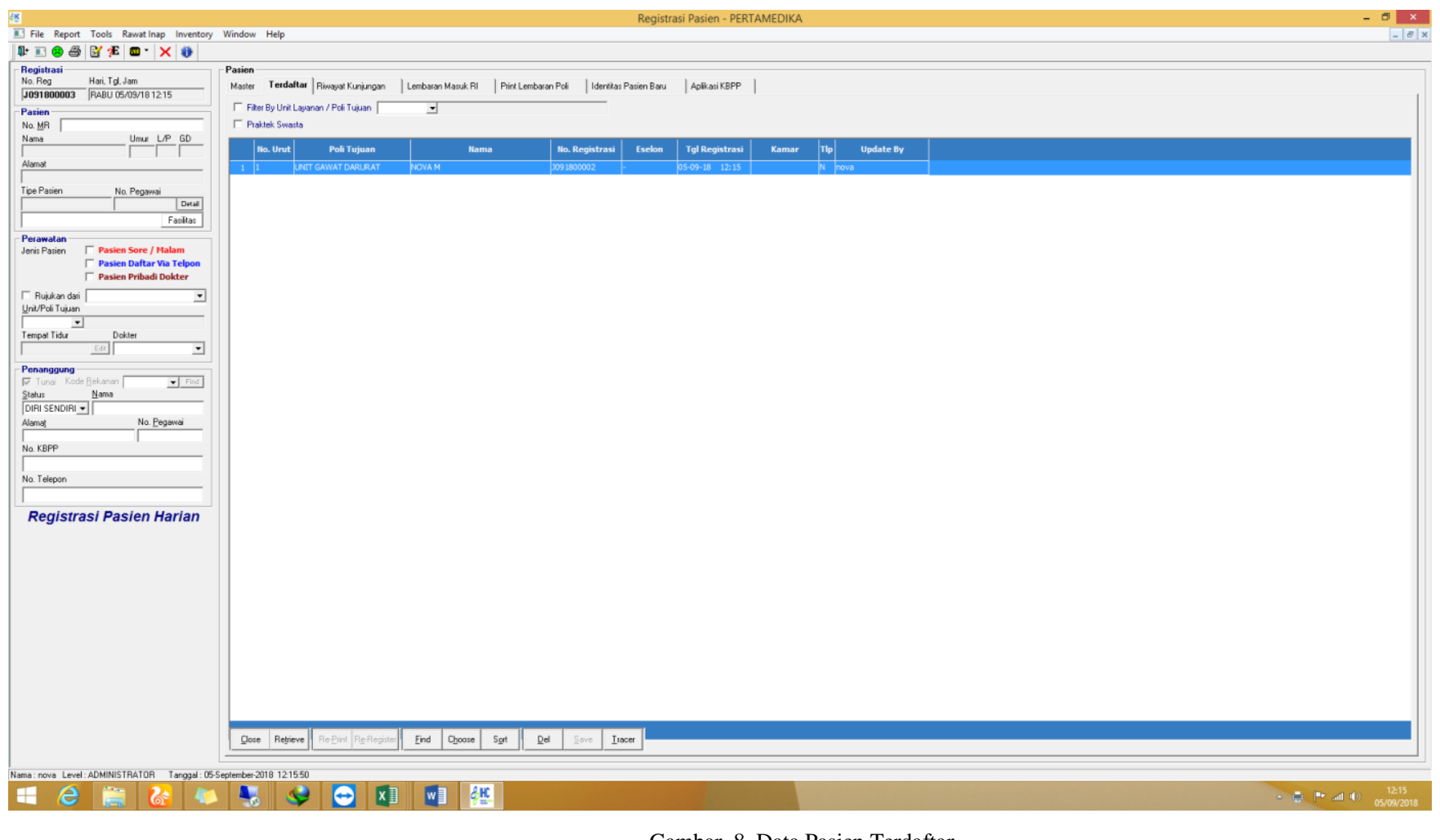

Gambar. 8. Data Pasien Terdaftar

\section{2) Proses pengentrian obat oleh dokter (e-Prescribing)}

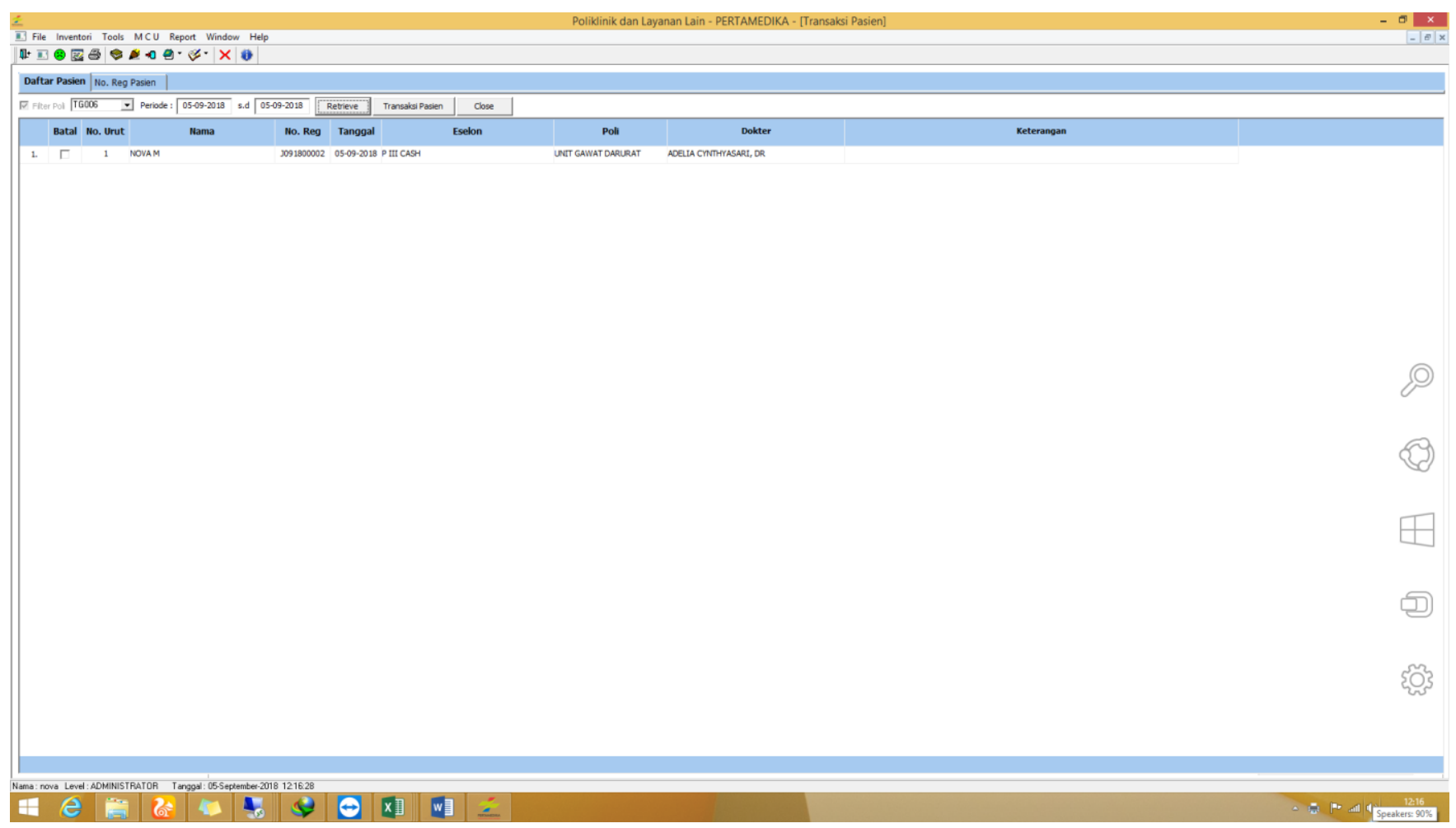

Gambar 9. Data Pasien Pada saat Transaksi pasien oleh Layanan Poliklinik 
JTIULM - Volume 03, Nomor 2, Oktober 2018: 59 - 70

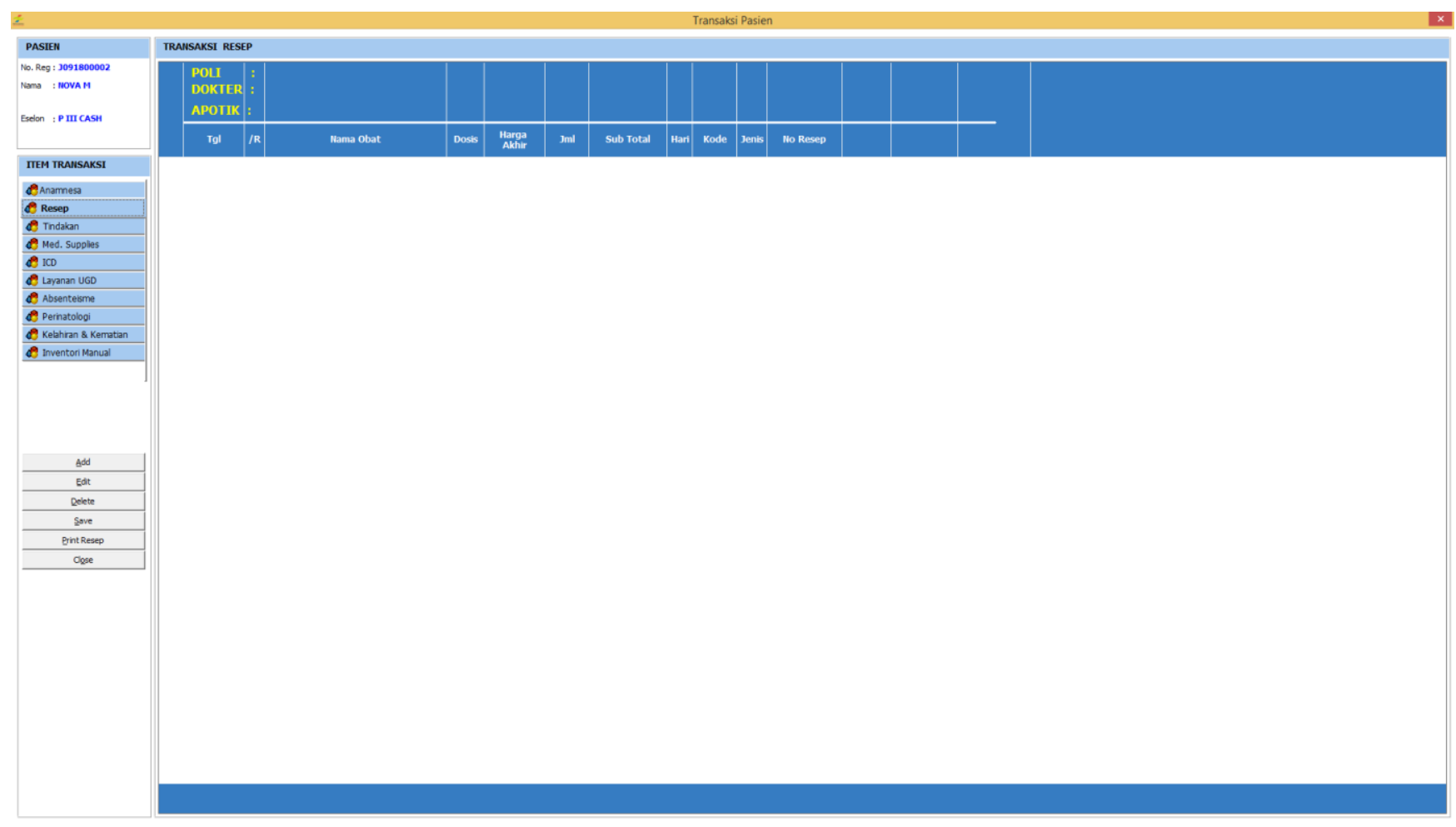

Gambar 10. Transaksi Resep Pasien

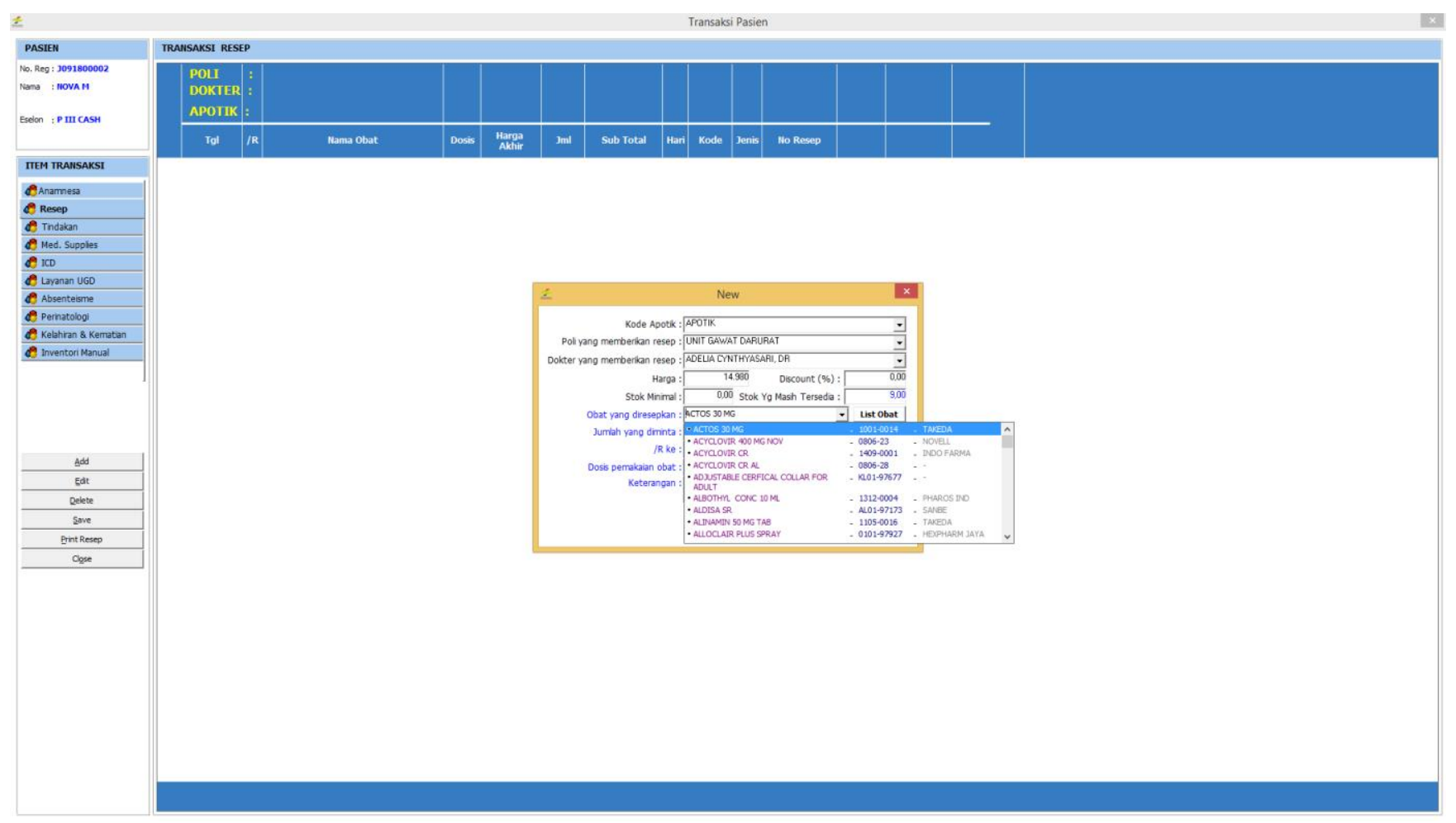

Gambar 11. Form Insert Resep Obat 
Alfah, Megariani, dan Rusdina - Sistem E - Prescribing Dan Barcode System Untuk Resep Obat Di Rumah Sakit

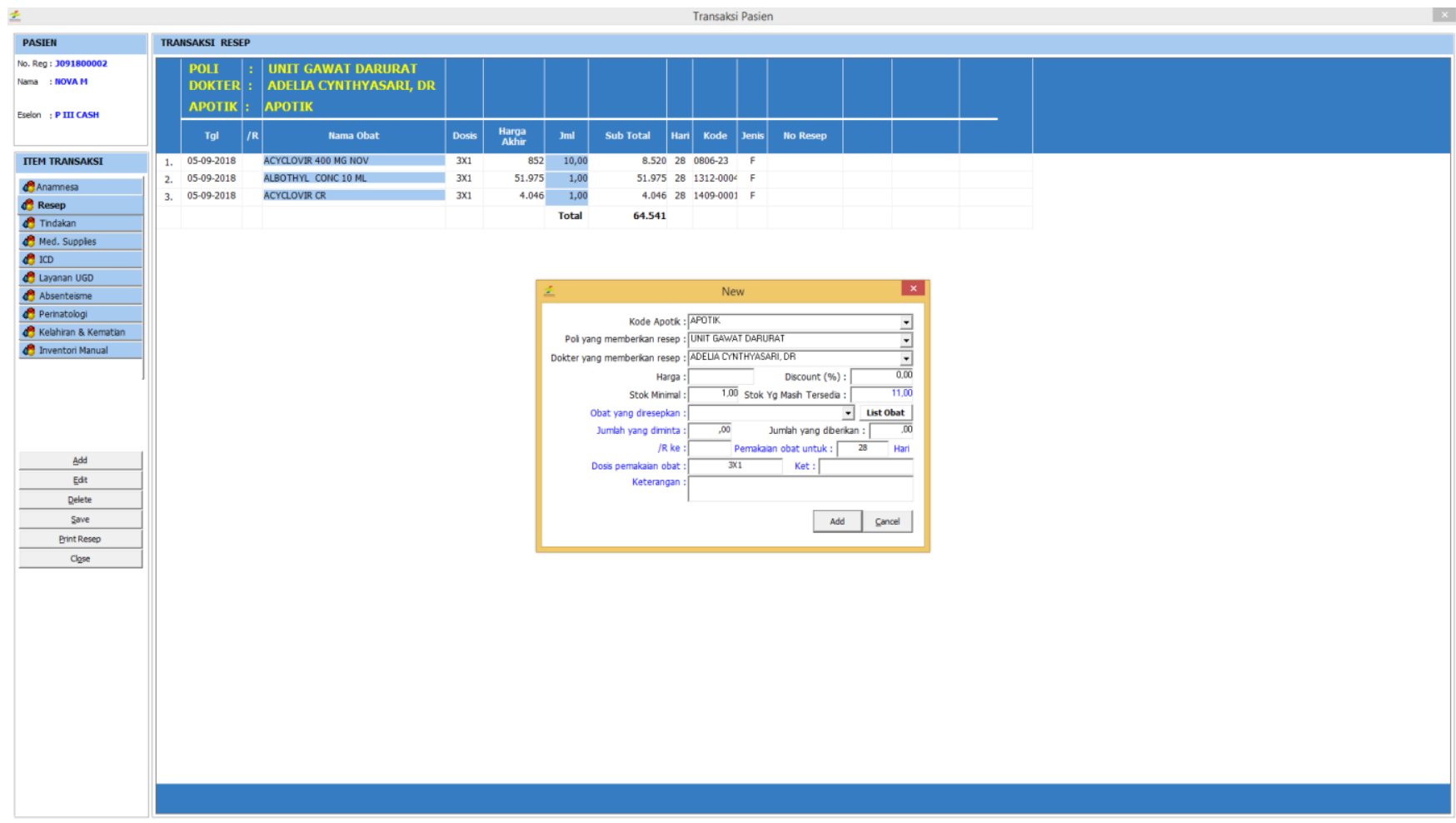

Gambar 12. Data Transaksi Resep Oleh Dokter Untuk Pasien

\section{3) Proses terima obat diapotik}

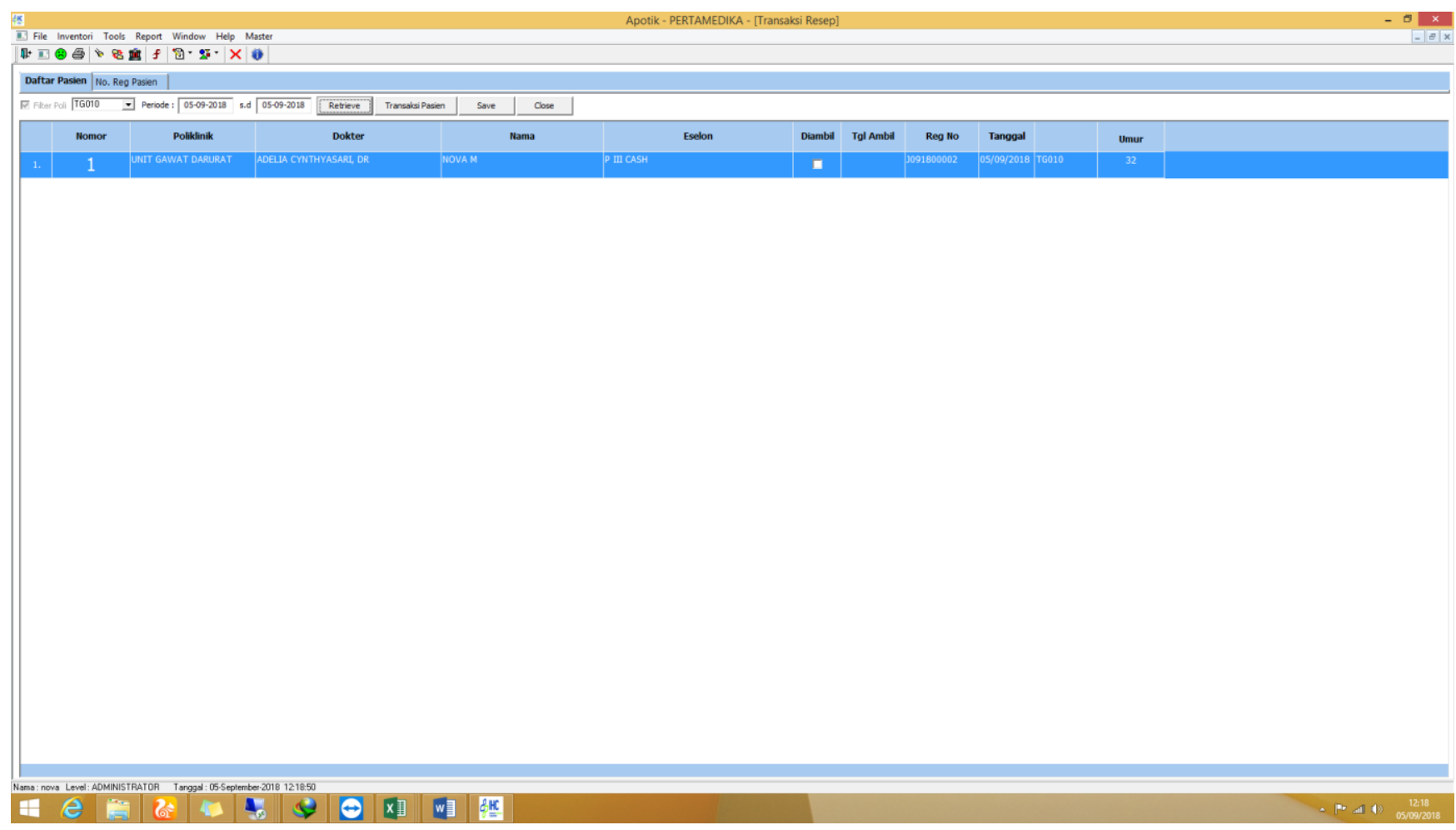

Gambar 13. Data Obat Yang Diinput Dokter/Perawat Yang Masuk Ke Apotik 


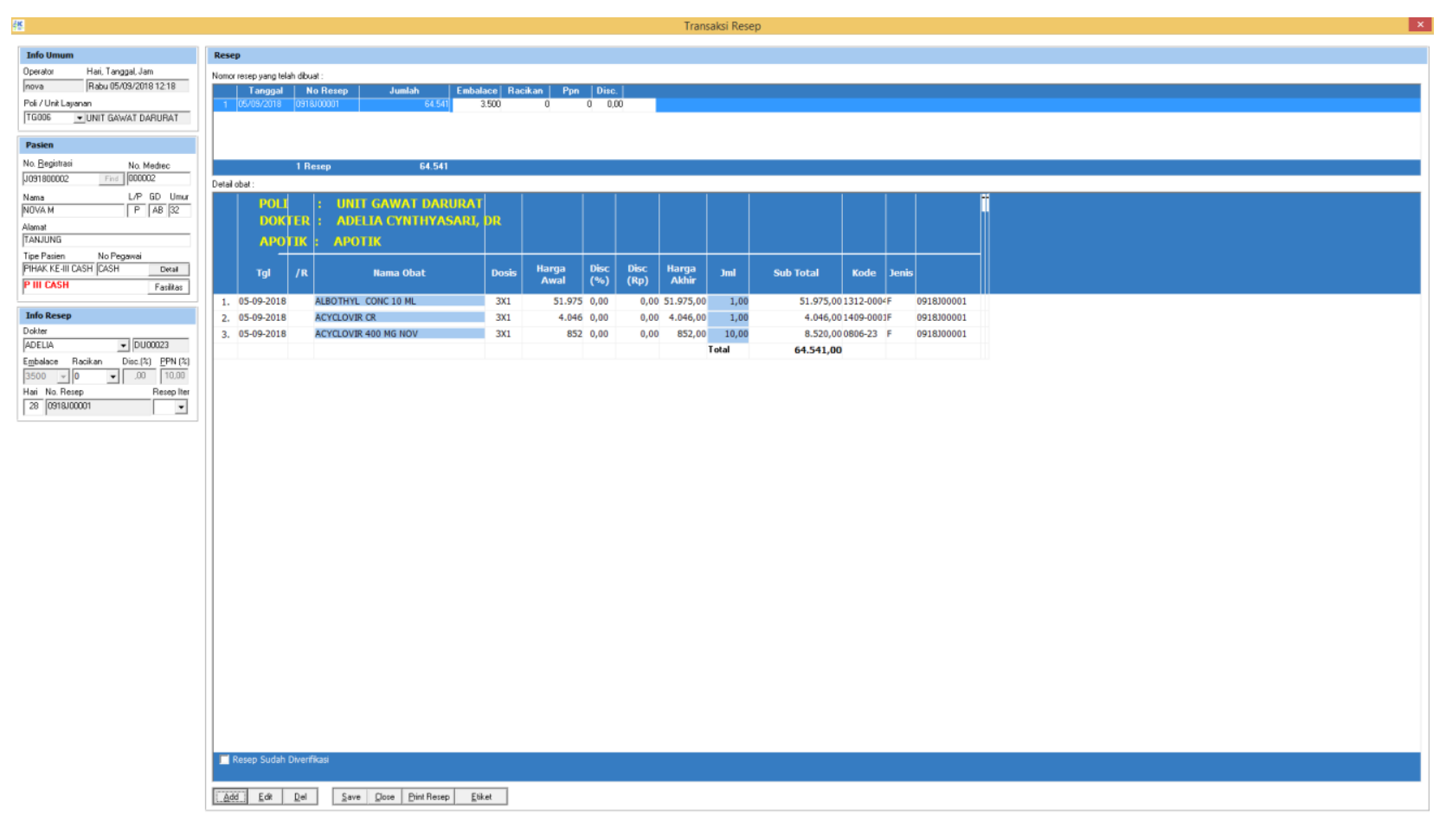

Gambar 14. Data Transaksi Obat Sesuai Resep Digital Yang Akan Diberikan Ke Pasien

\section{4) Proses pemberian obat ke pasien}

Obat diberikan ke pasien dengan barcode yang tertera pada print out resep apakah obat tersebut benar yang diberikan, apakah obat tersebut dosisnya sama, dan lain-lain. Barcode adalah representasi visual informasi dalam bentuk bar dan spasi di permukaan [8] sehingga memudahkan dalam pemotongan stok obat di apotik. Setelah aplikasi sudah diimplementasi kan ke objek penelitian, kami melakukan pembagian kuesioner kepada para pengguna/user yang ada. Ada 33(tiga puluh tiga) responden yang berpartisipasi, yaitu 18(delapan belas) orang dokter jaga disetiap Poli, 6(enam) orang apotek/apoteker dan 9(sembilan) orang perawat jaga. Kami menggunakan motode Skala Likert dalam mengukur kuesioner yang kami bagikan tersebut. Pertanyaan kuesioner meliputi Performance, Durability, Confermence to Specipication, Feature, realibity dan estetika.

\section{PENUTUP}

\section{A. Kesimpulan}

Berdasarkan hasil penelitian yang telah dilakukan yaitu pembuatan Aplikasi E-Prescribing dan Barcode sistem menggunakan Power Builder v12.6 dan Database Sybase pada rumah sakit Pertamina Tanjung, maka dapat disimpulkan bahwa aplikasi ini dapat mengurangi medication error yang terjadi pada pembuatan resep dokter oleh apoteker/asisten apoteker. Hasil praktis menunjukkan bahwa penggunaan komponen yang dapat digunakan kembali dapat meningkatkan efisiensi pengembangan perangkat lunak [9]. Dari hasil uji kuesioner yang kami berikan kepada user/pemakai Aplikasi E-Pescribing dan barcode system, didapatkan hasil yang memuaskan yaitu: untuk Performance sebanyak $81.82 \%$, Durability $84,24 \%$, Confermence to Specipication untuk hak akses apotek sebanyak $93 \%$. Sedangkan untuk hak akses poli/dokter yaitu $86,6 \%$, untuk Feature $84,24 \%$, realibity $83,64 \%$, dan estetika 79,4\%.

\section{B. Saran}

Dalam Pengembangan Aplikasi selanjutnya, Aplikasi E-Prescribing menggunakan barcode system sebaiknya menggunakan server tersendiri khusus rumah sakit itu sendiri sehingga mengurangi resiko data masuk yang terlambat dan sebagainya.

\section{UCAPAN TERIMA KASIH}

Terima Kasih Yang tak terhingga kepada semua pihak yang sudah membantu terselesaikan nya penelitian ini terutama Pihak KEMENRISTEKDIKTI dan Pihak LP2M UNISKA Banjarmasin, Fakultas Teknologi Informasi UNISKA Banjarmasin, Teknik Informatika Universitas Lambung Mangkurat Banjarmasin dan pihak lainnya yang tidak bisa disebutkan satu -persatu. Penelitian ini merupakan Penelitian Dosen Pemula yang Dibiayai oleh Dikti 2017/2018. 


\section{DAFTAR PUSTAKA}

[1] P. S. d. L. A. Pratiwi, "E-Prescribing : Studi Kasus Perancangan dan Implementasi Sistem Resep Obat Apotik Klinik," Indonesian Jurnal on Computer Science-Speed-IJCSS, vol. 10, no. 4, p. 9-14, 2013.

[2] V. S. Budihardjo, "Faktor Perawat Terhadap Kejadian Medication Administration Error Di Instalasi Rawat Inap,” Jurnal Administrasi Kesehatan Indonesia, vol. 5, no. 1, p. 53, 2017.

[3] Sudirohusodo, "Gambaran medication error pada fase prescribing dan administrasi pada pengobatan stroke di IGD Rumah Sakit X di Yogyakarta," pharmaciana, vol. 7, no. 1, pp. 25-32, 2017.

[4] S. N. K. S. M. N. M. Z. Hashim, "Development of Student Information System," International Journal of Science and Research (IJSR), vol. 2, no. 8, pp. $256-260,2013$.

[5] C. f. M. \&. M. Services, E-Prescribing, USA: http://www.cms.gov, 2008.

[6] 1. d. N. A. R. Widjaya, "Pengaruh Peresepan Elektronik Terhadap Mutu Layanan Farmasi Di Rumah Sakit "X" Jakarta Barat," Puspen Jurnal UEU, 2013.

[7] J. K. V. R. H. C. L. d. M. H. Gao, “A 2D barcode-based mobile payment system,” dalam In 3rd International Conference on Multimedia and Ubiquitous Engineering, MUE 2009, China, 2009.

[8] N. M. Z. I. N. a. S. N. M. S. F. \&. Z. Z. Hashim, "Barcode Recognition System," International Journal of Emerging Trends \& Technology in Computer Science (IJETTCS), vol. 2, no. 4, p. 278-283, 2013.

[9] Z. Z. X. \&. H. L. Tang, "Design and implementation of reusable components using PowerBuilder,” Procedia Engineering , vol. 29 , p. 584-588, 2012. 
JTIULM - Volume 03, Nomor 2, Oktober 2018: 59 - 70 